\title{
Enhancing the Co-ensiling Performance of Corn Stover and Cabbage Waste via the Addition of Cellulase
}

\author{
Haiwei Ren, ${ }^{\mathrm{a}}$ Li Wang, ${ }^{\mathrm{a}}$ Yanan Sun, ${ }^{\mathrm{a}}$ Quanlin Zhao, ${ }^{\mathrm{a}, \mathrm{b}}$ Yongming Sun, ${ }^{\mathrm{b}}$ Jinping Li, ${ }^{\mathrm{a}}$ and \\ Bingyun Zhang a,*
}

\begin{abstract}
Effects of cellulase addition were assessed relative to the co-ensiling performance of air-dried corn stover (DCS) and cabbage waste (CW). The DCS and CW mixtures were co-ensiled with 0 to $0.3 \%$ of cellulase addition, and changes in composition, intermediates, and biological activity were characterized. The results showed that the addition of cellulase enhanced the decomposition of cellulose and hemicellulose by 2.51 to $6.93 \%$ and $3.41 \%$, based on different dosages and compared with the control. Thus, the content of water-soluble carbohydrates increased. The acid content also increased from $5.8 \%$ for the control to the range 5.16 to $8.51 \%$ for the samples containing cellulase. Moreover, there was a shift from homolactic to heterolactic fermentation with prolonged ensiling time, coupled with the dominant lactic acid bacteria shifting from Paralactobacillus and Lactobacillus to more of Lactobacillus. Thus, the addition of cellulase improved the relative abundance of Lactobacillus. An assessment of fermentation quality, therefore, suggested that cellulase addition can improve the silage quality of DCS/CW during co-ensiling.
\end{abstract}

Keywords: Cellulase; Ensiling quality; Microbial community; Lactic acid bacteria

Contact information: a: School of Life Science and Engineering, Lanzhou University of Technology / Key Laboratory of Complementary Energy System of Biomass and Solar Energy, Lanzhou 730050, P. R. China; b: Guangzhou Institute of Energy Conversion, Chinese Academy of Sciences, Guangzhou 510640, China;

*Corresponding author:494467885@qq.com

\section{INTRODUCTION}

Over the past few decades, human activity has led to an increasing amount of agricultural waste, such as crop stalk, fruit, and vegetable waste. In agricultural production, an urgent need has emerged to solve the problem of waste disposal (Hillion et al. 2018). Agricultural residues are regarded as an attractive alternative for bioenergy production due to their wide availability, environmental friendliness, low cost, and renewability, and because they do not compete with food crops (Hess et al. 2009; Vervaeren et al. 2010). However, the drawback of seasonal production and short harvest times negatively affects the large-scale utilization of agricultural waste. Consequently, controlling the long-term preservation and real-time disposition of agricultural waste is indispensable for ensuring year-round availability and sustainable food throughout the year for bioenergy production.

Ensiling is an anaerobic wet storage method and represents a feasible and costeffective way to supply year-round biomass (Gallegos et al. 2018). During the ensiling process, lactic acid bacteria (LAB) convert water-soluble carbohydrates (WSCs) into organic acids, reducing the $\mathrm{pH}$ to a range of 3.5 to 4.2 , which inhibits the growth of undesirable microorganisms and preserves the organic matter of biomass (Janke et al. 2019). Satisfactory silage preservation depends on intrinsic biochemical characteristics, such as the moisture, carbohydrate content, and the buffering capacity of biomass and 
storage conditions, which includes temperature, time, and packing density. Among these, moisture content and WSCs are important for enhancing LAB activity and organic acid generation (Zhao et al. 2016). Studies have shown that ensiling with a moisture content ranging from $65 \%$ to $75 \%$, and a rudimentary soluble carbohydrate content higher than $5 \%$ (dry matter, DM), is favorable for lactobacillus reproduction (Hillion et al. 2018). However, obtaining good silage quality on an industrial scale may is challenging, as the soluble sugar content in agro-industrial organic waste is insufficient for producing enough lactic acid. Thus, air-dried crop stalk is difficult to immediately ensile due to its low moisture, sugar, and high fiber content (Vervaeren et al. 2010). Although co-ensiling of dried crop stalk with other agro-industrial waste material, such as vegetable waste and sugar beet leaves, may achieve well-preserved silages, the natural cross-linked recalcitrant structure of dried crop stalk may hinder efficient lactic fermentation (Hillion et al. 2018; Ren et al. 2018; Chen et al. 2019).

Various additives, including lactic acid bacteria, enzyme, and molasses, have been used in ensiling to improve silage quality and break down the cell wall components (Li et al. 2014; Muck et al. 2018). Of these, fibrolytic enzymes can enhance LAB activity by promoting the release of sugar from lignocellulosic biomass, which improves ensiling performance at a lower $\mathrm{pH}$ and produces more lactic acid (Sun et al. 2011). Previous studies have confirmed that fibrolytic enzymes can increase the concentration of lactic acid and soluble carbohydrates and decrease the content of hemicellulose and cellulose in the silage (Lynch et al. 2015; Desta et al. 2016). Li et al. (2018) also reported that silage with added fibrolytic enzymes maintained lower levels of acid detergent lignin (ADL) throughout the ensiling process of Pennisetum sinese. In addition, fibrolytic enzymes can improve the digestibility of structural carbohydrates, especially neutral detergent fibers (NDF), during the first $24 \mathrm{~h}$ of incubation (Colombatto et al. 2004a; Romero et al. 2015). Therefore, before silage production, cellulolytic enzyme pretreatment is considered a beneficial biological pretreatment for lignocellulosic biomass for the production of bioenergy and biological products. This process can decompose the persistent structural matrix, change the composition of lignocellulose, and increase the conversion rate of cellulose (Sun et al. 2011; Desta et al. 2016; Wu et al. 2020). Thus, a better understanding of enzyme addition for altering the microbial communities in ensilage is needed in order to effectively improve silage quality.

Though reports have shown that both ensiling and the use of additives are effective strategies for the preservation and valorization of agricultural waste, and are a beneficial pretreatment method for downstream biorefining, to the best of our knowledge, there is a lack of research on the effects of additives applied during the ensiling of air-dried corn stover and cabbage waste. Therefore, the objectives of this study were to (1) determine the effect of cellulase addition for the co-ensiling performance of corn stover and cabbage waste in terms of fermentation characteristics and chemical composition, and (2) assess the evolution of microbial community diversity during co-ensiling with various cellulase dosages. 


\section{EXPERIMENTAL}

\section{Materials}

Raw material and silage additives

Air-dried corn stover (DCS) was cultivated and harvested in October from local farms in Yuzhong County (latitude $35.34^{\circ} \mathrm{N}$, longitude $103.49^{\circ} \mathrm{E}$, and altitude $1874.4 \mathrm{~m}$ a.s.l., Gansu Province, China). The material was chopped mechanically into lengths of 10 to $20 \mathrm{~mm}$. In this location, the average annual temperature is $7.9^{\circ} \mathrm{C}$, and the hottest and coldest monthly average temperatures are $35.8{ }^{\circ} \mathrm{C}$ (July) and $-11{ }^{\circ} \mathrm{C}$ (January), respectively. In addition, the annual average precipitation is between 300 and $400 \mathrm{~mm}$, the annual average solar radiation is $4800 \mathrm{MJ} / \mathrm{m}^{2}$, and the region receives an annual average of $2562.5 \mathrm{~h}$ of sunshine. The cabbage waste $(\mathrm{CW})$ was obtained from the Qilihe vegetable market in Lanzhou (latitude $35.55^{\circ} \mathrm{N}$, longitude $103.50^{\circ} \mathrm{E}$, altitude $1800.4 \mathrm{~m}$ a.s.L., Gansu Province, China) and cut into $20 \mathrm{~mm} \times 20 \mathrm{~mm}$ pieces. The moisture content values of DCS and CW before ensiling were $10.23 \%$ and $91.41 \%$ on a fresh mass basis, respectively. The commercial cellulase (Ningxia Imperial Jade Biotechnology, Ltd., Yinchuan City, China), which consisted of $\beta$-glucanase, $\alpha$-arazyme, $\alpha$-galactosidase, $\beta$-galactosidase, and $\beta$ xylanase (> 10,000 U/g), was supplied as a freeze-dried powder.

\section{Methods}

Co-ensiling of DCS and CW

The chopped DCS and CW were mixed thoroughly and divided into a total of 48 equivalent piles (3.23 kg of DCS and $9.87 \mathrm{~kg}$ of $\mathrm{CW}$ for each pile, wet basis) for experimental treatment according to our previously published methods (Ren et al. 2018). The three blended piles were immediately frozen at $-20{ }^{\circ} \mathrm{C}$ for further analysis. The remaining 45 piles ( 5 ensiling time points $\times 3$ dosage treatments $\times 3$ replicates) were randomly assigned into the following treatment groups: (1) control without additives (CWA), (2) cellulase applied at a low dosage of $0.1 \%$ (w/w, fresh weight) (CLD), and (3) cellulase applied at a high dosage of $0.3 \%$ (w/w, fresh weight) (CHD). The cellulase for each treatment was dissolved in $10 \mathrm{~mL}$ of distilled water and uniformly sprayed on each pile of silage. For the control group, the same amount of distilled water was applied. All treatments were adjusted to an approximate DM content of 30\%, compacted, and filled and sealed in $30 \mathrm{~L}$ cylindrical polyethylene plastic buckets (no headspace). All of the buckets were stored at $18 \pm 1{ }^{\circ} \mathrm{C}$ and sampled after $30,60,90,130$, and 170 days.

\section{Fermentation characteristics of silages}

After opening the buckets on the designated ensiling day, a $50 \mathrm{~g}$ sample was homogenized with $450 \mathrm{~mL}$ of distilled water for $1 \mathrm{~min}$ (JJ-2; Guohua Instruments Co., Ltd., Suzhou, China). After filtration through four layers of medical gauze and centrifuged at 3,900 rpm for $10 \mathrm{~min}$, the supernatant was obtained for $\mathrm{pH}$ measurements using a glass electrode $\mathrm{pH}$ meter (UB-7, DANFO, Beijing, China). Then, a portion of the supernatant was acidified by $50 \% \mathrm{H}_{2} \mathrm{SO}_{4}(\mathrm{w} / \mathrm{w})$ and filtered with a $0.22 \mu \mathrm{m}$ dialyzer to analyze the organic acids (lactic, acetic, propionic, and butyric acid) with an Agilent 1260 highperformance liquid chromatography (HPLC) system (Agilent Technologies, Inc., Waldbronn, Germany). The system was fitted with a refractive index detector (RSpak KC811, Shodex, Tokyo, Japan; eluent: $3 \mathrm{mmol} / \mathrm{L} \mathrm{HClO}_{4}$, flow rate: $1 \mathrm{~mL} / \mathrm{min}$, injection volume: $5 \mu \mathrm{L}$, and temperature: $\left.50^{\circ} \mathrm{C}\right)(\mathrm{Li}$ et al. 2019). After protein precipitation formed by trichloroacetic acid, ammonia nitrogen (AN) content was determined using the phenol- 
hypochlorite colorimetric method and expressed per total nitrogen (g/kg TN) (Ren et al. 2021).

\section{Chemical composition analysis}

The chemical compositions of the dry matter (DM), total nitrogen (TN), neutral detergent fiber (NDF), acid detergent fiber (ADF), and acid detergent lignin (ADL) were analyzed according to previously reported methods (Ni et al. 2017). Holocellulose (HoC) content was the sum of hemicellulose (HC) and cellulose (CL) content (Robinson et al. 2016). The biodegradation potential of the silage was estimated as the ratio of (hemicellulose + cellulose) to lignin (Vandecasteele et al. 2017). Thus, the carbohydrate content was extracted and used to measure the WSC content using the 3,5-dinitrosalicylic acid (DNS) method with glucose as the standard (Leyva et al. 2008). The TN was equivalent to the Kjeldahl nitrogen, which was determined by a Kjeldahl nitrogen analyzer (K9840, Hanon instruments Co., Ltd., Jinan, China) (Li et al. 2019). All analyses were performed in triplicate. A Flieg evaluation system was used to evaluate the quality of the silage by scoring the silage and by scoring the ratio of the lactic acid, acetic acid, and butyric acid to the total acid content (Agneessens et al. 2015).

\section{Microbial Community Analysis}

Metagenomic DNA extraction

Samples from the treatment of CWA and CHD were selected to analyze the dynamic changes in the microbial communities during the ensiling process, using highthroughput sequencing technology. A total of $20 \mathrm{~g}$ of samples was mixed with $180 \mathrm{~mL}$ of sterilized $\mathrm{NaCl}$ solution $(0.85 \%)$ and then treated with a table concentrator at $120 \mathrm{rpm}$ for $2 \mathrm{~h}$. The suspension was then filtered to obtain the microbial cells for DNA extraction. Total DNA content was extracted using a water DNA extraction kit (Fuji Biotechnology Co., Ltd., Chengdu, China), and DNA quantity and quality were assessed by agarose gel electrophoresis. High-molecular-weight DNA samples (minimal concentration of 20 $\mathrm{ng} / \mu \mathrm{L})$ were used for sequencing.

\section{PCR amplification}

Amplification of the V3-V4 hypervariable region of the 16S rRNA was achieved using 338F (5-ACTCCTACGGGAGGCAGCA-3) and 806R (5-GGACTACHVGGGTW TCTAAT-3) primers. Amplification of the targeted region was achieved using the following reaction chemistry: $5 \mu \mathrm{L}$ of Gotaq Green master mix (Promega, Madison, WI, USA), $11.9 \mu \mathrm{L}$ of DNase free water, $0.5 \mu \mathrm{L}$ of $\mathrm{MgCl}_{2}(50 \mathrm{mM}), 0.5 \mu \mathrm{L}$ of deoxynucleotide triphosphates $(10 \mathrm{mM}), 1 \mu \mathrm{L}$ of DNA forward and reverse primers $(10 \mu \mathrm{M})$, and $5 \mu \mathrm{L}$ of the DNA template were adjusted for all samples to a final average concentration of $1 \mathrm{ng} / \mu \mathrm{L}$ of total reaction volume. Reaction conditions for bacterial $16 \mathrm{~S}$ amplification were as follows: $95{ }^{\circ} \mathrm{C}$ for $3 \mathrm{~min}$, followed by 35 cycles of $95{ }^{\circ} \mathrm{C}$ for $45 \mathrm{~s}, 50{ }^{\circ} \mathrm{C}$ for $60 \mathrm{~s}$, and 72 ${ }^{\circ} \mathrm{C}$ for $90 \mathrm{~s}$. A final extension was conducted at $72{ }^{\circ} \mathrm{C}$ for $10 \mathrm{~min}$ (He et al. 2015). After a second examination with gel electrophoresis, the polymerase chain reaction (PCR) products were denatured with $\mathrm{NaOH}$ to generate single-strand DNA fragments, which were sequenced using an Illumina MiSeq platform (Personalbio Biotechnology, Ltd., Shanghai, China).

High-throughput sequencing of metagenomics DNA

To obtain the high-quality clean reads, quality filtering of the raw reads was 
performed under specific filtering conditions. Chimera sequences from the bacteria were removed using the UCHIME algorithm by comparing them with the Silva database. However, chimeral sequences of fungal materials were removed using the UCHIME algorithm by comparing them with the UNITE database. The effective sequences (reads) were counted and operational taxonomic units (OTUs) were clustered at 97\%, at similar levels for performing the taxonomic analysis of different samples and obtaining microbial community composition at different levels. Alpha diversity analysis was conducted using QIIME software (http://qiime.org/) to analyze species richness (Chao1, ACE index) and diversity (Shannon and Simpson index). Beta diversities of both weighted and unweighted UniFrac were calculated using QIIME software. Subsequently, species with a relative abundance higher than $0.1 \%$ were selected for microbial community composition analysis.

\section{Statistical Analysis}

The experiment design consisted of a $3 \times 5$ factorial design with 3 dosages and 5 ensiling times. The statistical model follows,

$$
Y=\mu+\alpha_{\mathrm{i}}+\beta_{\mathrm{j}}+(\alpha \times \beta)_{\mathrm{ij}}+\varepsilon_{\mathrm{ij}},
$$

where $Y$ represents the response variable, $\mu$ is the overall mean, $\alpha_{\mathrm{i}}$ is the effect of the ensiling period, $\beta_{\mathrm{j}}$ is the effect of different additive dosages (treatments), $(\alpha \times \beta)_{\mathrm{ij}}$ is the interaction effect between the ensiling period and additive dosages, and $\varepsilon_{\mathrm{ij}}$ is the residual error (Li et al. 2020). Data were analyzed using the general linear model procedure from the statistical package for social science (SPSS 18.0, SPSS Inc., Chicago, IL, USA), and one-way analysis of variance (ANOVA) was determined using Tukey's multiple comparison test at a significance level of 0.05 .

\section{RESULTS AND DISCUSSION}

\section{Comparison of Composition between the Mixtures and Raw Material}

The chemical compositions of the DCS and CW are presented in Table 1. The dry matter of the DCS was $89.77 \pm 0.01 \%$ (Table 1 ). DCS moisture content $(10.23 \%$ ) was lower than the proper value for ensiling (Adesogan and Newman 2014). Moreover, the WSC content of DCS was $8.05 \pm 0.03 \%$, which was lower than the essential WSC content for high-quality silage (8 to 10\%). However, dry matter and WSC values in the CW were $8.59 \pm 0.15 \%$ and $14.57 \pm 0.02 \%$, respectively. In general, the production of high-quality silage requires a raw material with 35 to $45 \%$ of DM content and 8 to $10 \%$ of WSC content (Agneessens et al. 2015). After mixing, the dry matter and WSC content of the mixtures were $29.56 \pm 0.03 \%$ and $9.53 \pm 0.20 \%$, respectively. Compared with the chemical compositions of the raw materials, the mixture had more suitable moisture and WSC content, compared to DCS or CW alone, indicating that the mixtures had optimal compositions for lactic acid fermentation.

The contents of NDF, ADF, and ADL of DCS were $76.85 \%, 47.15 \%$, and $8.12 \%$, respectively (Table 1). After mixing, an increase of $22.54 \%$ in ADL content and decreases of $11.95 \%$ and $0.07 \%$ in $\mathrm{NDF}$ and $\mathrm{ADF}$ content were observed for the mixtures, respectively. Optimal cellulase content provides a sufficient source of lactic acid fermentation substrate, thereby promoting the reduction in $\mathrm{pH}$ and inhibiting harmful microorganisms (Li et al. 2020). Therefore, the co-ensiling of DCS and CW was proposed in this study as a simple and low-cost strategy for storing both waste products. 
Table 1. Chemical Compositions of Air-dried Corn Stover and Cabbage Waste

\begin{tabular}{|c|c|c|c|}
\hline Items & $\begin{array}{c}\text { Cabbage } \\
\text { waste }\end{array}$ & Air-dried corn stover & After mixing \\
\hline Dry matter (\% FW) & $8.59 \pm 0.15$ & $89.77 \pm 0.01$ & $29.56 \pm 0.03$ \\
\hline Water soluble carbohydrate (\% DM) & $14.57 \pm 0.02$ & $8.05 \pm 0.03$ & $9.53 \pm 0.20$ \\
\hline Acid detergent fiber (\% DM) & $33.27 \pm 0.97$ & $47.15 \pm 0.01$ & $44.01 \pm 1.09$ \\
\hline Neutral detergent fiber (\% DM) & $36.25 \pm 1.20$ & $76.85 \pm 0.02$ & $67.67 \pm 0.39$ \\
\hline Acid detergent lignin (\% DM) & $16.21 \pm 0.45$ & $8.12 \pm 0.03$ & $9.95 \pm 0.21$ \\
\hline Cellulose (\% DM) & $17.06 \pm 0.64$ & $39.03 \pm 0.02$ & $34.06 \pm 1.08$ \\
\hline Hemicellulose (\% DM) & $2.98 \pm 0.46$ & $29.70 \pm 0.02$ & $23.66 \pm 0.74$ \\
\hline Holocellulose (\% DM) & $20.04 \pm 0.53$ & $68.73 \pm 0.05$ & $57.72 \pm 0.34$ \\
\hline ADF:NDF & 0.91 & 0.61 & 0.65 \\
\hline ADL:NDF & 0.45 & 0.11 & 0.15 \\
\hline ADL:ADF & 0.49 & 0.17 & 0.23 \\
\hline BDP & 3.89 & 2.62 & 2.93 \\
\hline
\end{tabular}

DM: dry matter; FW: fresh weight

\section{Effect of Cellulase on Co-ensiling Quality}

Changes in lignocellulosic composition during the ensiling process

The effects of cellulase on the mixture composition during the ensiling process are listed in Table 2. With prolonged silage time, the NDF, ADF, and ADL content in the CWA groups ranged from $67.67 \pm 0.39 \%$ to $74.52 \pm 0.15 \%, 44.01 \pm 1.09 \%$ to $48.04 \pm 0.53 \%$, and $4.65 \pm 0.07 \%$ to $10.98 \pm 0.85 \%$, respectively, during ensiling periods of 30 to 170 days. Compared with the CWA group, CLD and CHD treatments had lower HC and CL content ( $\mathrm{P}<0.05$ ), with decreases of $13.55 \%, 26.60 \%$, and $44.33 \%$ in NDF, ADF, and ADL content, respectively. Similarly, compared with the CWA group, decreases of $17.31 \%$ and 9.1\% in CL and $\mathrm{HoC}$ content were observed for the CLD and CHD treatment groups, respectively. Thus, the addition of cellulase could effectively promote the degradation of fiber content, and a higher dosage of cellulase could effectively reduce CL, ADF, and ADL contents. Cellulase can also promote fiber degradation, elevating the WSC production by enzymolysis and acid solubilization, which increases the availability of fermentation substrates for LAB to produce lactic acid ( $\mathrm{Li}$ et al. 2019; Hu et al. 2021). The present results were in good agreement with a previous study by Kholif et al. (2017), where NDF, $\mathrm{ADF}$, and CL contents were significantly decreased after ensiling. Based on the composition changes, the biodegradation potential of the various samples was assessed, and the results are presented in Table 2. The biodegradation potentials of the samples increased after 170 days of long-term co-ensiling. The CHD group met this requirement, but the CLD group did not obtain a similar result.

To further understand the effects of cellulase on DCS and CW co-ensiling, WSC content was quantified, and the results are presented in Fig. 1. WSC content in all three treatments decreased significantly $(\mathrm{P}<0.05)$ during the first 30 days of co-ensiling, with descent percentages of $79.64 \%, 72.19 \%$, and $60.13 \%$ in groups CWA, CLD, and CHD, 
respectively. This was attributed to the quick growth and proliferation of aerobic microorganisms, with abundant fermentation substrates during the initial stage. With more ensiling time, the CLD and CHD groups exhibited increasing trends in WSC content after 30 and 90 days, respectively. Moreover, the CLD and CHD groups showed significantly higher amounts of WSC than CWA during the storage period of 30 to 170 days, which was consistent with the report that cellulase indirectly provided fermentable sugars from the degradation of NDF, ADF, and HC, and thus required more time (Hess et al. 2009). Weinberg and Chen (2013) suggested that cell-wall degradation enzymes can release fermentable sugars and cause a decrease in fiber content, which was responsible for the observed enhanced digestibility. Furthermore, the WCS content in the CLD group was significantly higher $(\mathrm{p}<0.05)$ than in the CHD group between 60 and 170 days of coensiling. This indicated that a low dose of cellulase was beneficial for the preservation of WSC.

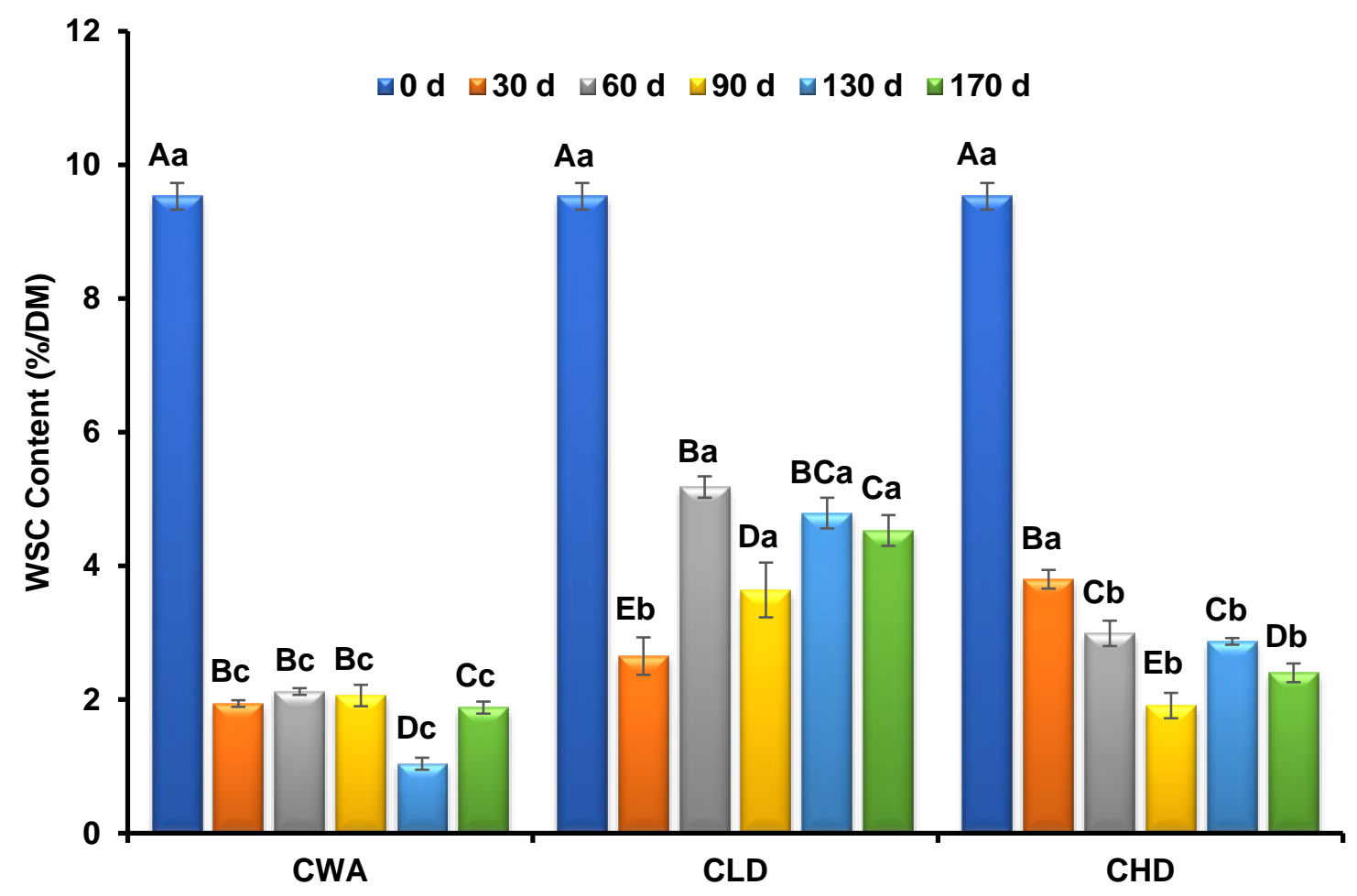

Fig. 1. Dynamic effects of cellulase dosage on WSC content: CWA contained no cellulase, CLD contained a low dose of cellulase $(0.1 \%)$, and CHD contained a high dose of cellulase $(0.3 \%)$. The different lowercase letters indicate significant differences at $p<0.05$ between different groups at the same time, and different capital letters indicate significant differences at $p<0.05$ for the same groups at different times. 
Table 2. Compositions of Air-dried Corn Stover and Cabbage Waste Mixtures during Co-ensiling (\%DM)

\begin{tabular}{|c|c|c|c|c|c|c|c|c|}
\hline & $\begin{array}{l}\text { Time } \\
\text { (d) }\end{array}$ & NDF (\%) & ADF (\%) & ADL (\%) & $\begin{array}{l}\mathrm{HC} \\
(\%)\end{array}$ & $\begin{array}{l}\mathrm{CL} \\
(\%)\end{array}$ & $\begin{array}{l}\mathrm{HoC} \\
(\%)\end{array}$ & $\begin{array}{c}\text { Biodegradation } \\
\text { potential }\end{array}$ \\
\hline \multirow{6}{*}{ CWA } & 0 & $67.67 \pm 0.39 \mathrm{Da}$ & $44.01 \pm 1.09 \mathrm{Ca}$ & $9.95 \pm 0.21 \mathrm{Ba}$ & $23.66 \pm 0.74 \mathrm{Ca}$ & $34.06 \pm 1.08 \mathrm{Da}$ & $57.72 \pm 0.34 \mathrm{Da}$ & 5.80 \\
\hline & 30 & $71.34 \pm 0.14 \mathrm{Ca}$ & $44.54 \pm 0.43 \mathrm{BCa}$ & $5.88 \pm 0.26 \mathrm{~Eb}$ & $26.79 \pm 0.56 \mathrm{Aa}$ & $38.66 \pm 0.69 \mathrm{Ca}$ & $65.45 \pm 0.14 \mathrm{Ba}$ & 11.13 \\
\hline & 60 & $71.13 \pm 0.25 \mathrm{Ca}$ & $45.49 \pm 0.09 \mathrm{Ba}$ & $10.98 \pm 0.85 \mathrm{Ab}$ & $25.64 \pm 0.22 \mathrm{Bc}$ & $34.51 \pm 0.90 \mathrm{Da}$ & $60.15 \pm 0.77 \mathrm{Ca}$ & 5.48 \\
\hline & 90 & $74.52 \pm 0.15 \mathrm{Aa}$ & $47.40 \pm 0.36 \mathrm{Aa}$ & $4.65 \pm 0.07 \mathrm{Fc}$ & $27.12 \pm 0.48 \mathrm{Aa}$ & $42.75 \pm 0.33 \mathrm{Aa}$ & $69.88 \pm 0.22 \mathrm{Aa}$ & 15.03 \\
\hline & 130 & $71.67 \pm 0.01 \mathrm{Ca}$ & $44.78 \pm 0.04 \mathrm{BCa}$ & $7.07 \pm 0.35 \mathrm{Db}$ & $26.89 \pm 0.04 \mathrm{Ab}$ & $37.71 \pm 0.39 \mathrm{Ca}$ & $64.60 \pm 0.36 \mathrm{Ba}$ & 9.14 \\
\hline & 170 & $72.82 \pm 0.53 \mathrm{Ba}$ & $48.04 \pm 0.53 \mathrm{Aa}$ & $8.03 \pm 0.07 \mathrm{Cb}$ & $24.78 \pm 1.06 \mathrm{Bb}$ & $40.02 \pm 0.46 \mathrm{Ba}$ & $64.79 \pm 0.59 \mathrm{Ba}$ & 8.07 \\
\hline \multirow{6}{*}{ CLD } & 0 & $67.67 \pm 0.39 \mathrm{Aa}$ & $44.01 \pm 1.09 \mathrm{Ba}$ & $9.95 \pm 0.21 \mathrm{Ca}$ & $23.66 \pm 0.74 \mathrm{Da}$ & $34.06 \pm 1.08 \mathrm{Ba}$ & $57.72 \pm 0.34 \mathrm{Ca}$ & 5.80 \\
\hline & 30 & $66.56 \pm 0.13 \mathrm{Bb}$ & $41.63 \pm 0.09 \mathrm{Cb}$ & $4.47 \pm 0.01 \mathrm{Fc}$ & $24.93 \pm 0.09 \mathrm{Cb}$ & $37.16 \pm 0.08 \mathrm{Ab}$ & $62.08 \pm 0.12 \mathrm{Ab}$ & 13.89 \\
\hline & 60 & $64.84 \pm 0.24 \mathrm{Cb}$ & $35.26 \pm 0.08 \mathrm{~Eb}$ & $6.86 \pm 0.06 \mathrm{Ec}$ & $29.58 \pm 0.21 \mathrm{Aa}$ & $28.39 \pm 0.02 \mathrm{Db}$ & $57.98 \pm 0.22 \mathrm{Cb}$ & 8.45 \\
\hline & 90 & $67.68 \pm 0.37 \mathrm{Ab}$ & $42.15 \pm 0.14 \mathrm{Cb}$ & $12.40 \pm 0.40 \mathrm{Aa}$ & $25.53 \pm 0.22 \mathrm{Cb}$ & $29.75 \pm 0.26 \mathrm{Cc}$ & $55.27 \pm 0.05 \mathrm{Dc}$ & 4.46 \\
\hline & 130 & $65.15 \pm 0.15 \mathrm{Cc}$ & $38.65 \pm 0.10 \mathrm{Dc}$ & $11.61 \pm 0.25 \mathrm{Ba}$ & $26.50 \pm 0.22 \mathrm{Bc}$ & $27.04 \pm 0.14 \mathrm{Ec}$ & $53.54 \pm 0.34 \mathrm{Ec}$ & 4.61 \\
\hline & 170 & $67.43 \pm 0.40 \mathrm{Ab}$ & $46.06 \pm 0.08 \mathrm{Ab}$ & $8.55 \pm 0.34 \mathrm{Da}$ & $21.37 \pm 0.48 \mathrm{Ec}$ & $37.51 \pm 0.32 \mathrm{Ab}$ & $58.89 \pm 0.61 \mathrm{Bc}$ & 6.89 \\
\hline \multirow{6}{*}{$\mathrm{CHD}$} & 0 & $67.67 \pm 0.39 \mathrm{ABa}$ & $44.01 \pm 1.09 \mathrm{Aa}$ & $9.95 \pm 0.21 \mathrm{Ba}$ & $23.66 \pm 0.74 \mathrm{Da}$ & $34.06 \pm 1.08 \mathrm{Aa}$ & $57.72 \pm 0.34 \mathrm{Ca}$ & 5.80 \\
\hline & 30 & $63.86 \pm 0.04 \mathrm{Dc}$ & $40.06 \pm 0.09 \mathrm{CDc}$ & $6.46 \pm 0.21 \mathrm{Da}$ & $23.81 \pm 0.04 \mathrm{Dc}$ & $33.60 \pm 0.30 \mathrm{ABC}$ & $57.40 \pm 0.25 \mathrm{Cc}$ & 8.89 \\
\hline & 60 & $62.95 \pm 0.23 \mathrm{Ec}$ & $34.58 \pm 0.01 \mathrm{Ec}$ & $12.82 \pm 0.10 \mathrm{Aa}$ & $28.37 \pm 0.23 \mathrm{Ab}$ & $21.75 \pm 0.09 \mathrm{Cc}$ & $50.12 \pm 0.32 \mathrm{Dc}$ & 3.91 \\
\hline & 90 & $67.28 \pm 0.03 \mathrm{BCb}$ & $41.31 \pm 0.04 \mathrm{Bc}$ & $7.30 \pm 0.07 \mathrm{Cb}$ & $25.97 \pm 0.02 \mathrm{Cb}$ & $34.01 \pm 0.05 \mathrm{Ab}$ & $59.98 \pm 0.07 \mathrm{Bb}$ & 8.22 \\
\hline & 130 & $67.09 \pm 0.19 \mathrm{Cb}$ & $39.47 \pm 0.04 \mathrm{Db}$ & $6.65 \pm 0.03 \mathrm{Dc}$ & $27.62 \pm 0.22 \mathrm{Ba}$ & $32.82 \pm 0.01 \mathrm{Bb}$ & $60.44 \pm 0.21 \mathrm{ABb}$ & 9.09 \\
\hline & 170 & $67.93 \pm 0.41 \mathrm{Ab}$ & $40.35 \pm 0.04 \mathrm{Cc}$ & $7.26 \pm 0.21 \mathrm{Cc}$ & $27.58 \pm 0.36 \mathrm{Ba}$ & $33.09 \pm 0.25 \mathrm{Bc}$ & $60.67 \pm 0.61 \mathrm{Ab}$ & 8.36 \\
\hline
\end{tabular}

CWA: no cellulase addition; CLD: low dosage of cellulase (0.1\%); CHD: high dosage of cellulase (0.3\%); NDF: neutral detergent fiber; ADF: acid detergent fiber; ADL: acid detergent lignin; HC: hemicellulose; CL: cellulose; and HoC: holocellulose.

Same column with different lowercase letters indicates significant differences at $p<0.05$ between different groups at the same time, and the same column with different capital letters indicates significant differences at $p<0.05$ for the same groups at different times. 
Changes in $\mathrm{pH}$ and organic acid during the ensiling process

The $\mathrm{pH}$ values of the samples during co-ensiling were measured and are presented in Fig. 2. The results showed that the $\mathrm{pH}$ of all three groups decreased with prolonged ensiling time. The $\mathrm{pH}$ values of the CWA, CLD, and CHD groups after 30 days were 4.15, 4.08, and 3.91, respectively. In addition, the $\mathrm{pH}$ values of CWA, CLD, and CHD decreased to $3.92,3.72$, and 3.8 after 170 days of ensiling time, respectively. Furthermore, the $\mathrm{pH}$ values of the CLD and CHD groups were significantly $(\mathrm{p}<0.05)$ lower than the CWA group, indicating that the addition of cellulase significantly reduced the $\mathrm{pH}$ of the silage. Thus, a low dose of cellulase $(0.1 \%)$ showed better performance in maintaining a stable low $\mathrm{pH}$ compared to a higher $(0.3 \%)$ dosage, which was consistent with the results reported by Colombatto et al. (2004b). The decrease in $\mathrm{pH}$ also promoted the degradation of lignocellulose and the production of soluble carbohydrate content, as indicated by the changes in WSC, NDF, ADF, and HC content. Sargsyan et al. (2016) reported that a longterm acidic environment with a low $\mathrm{pH}$ can loosen the lignocellulosic structure of fibrous polymers, which can help decompose the cell wall (cellulose and hemicellulose) due to the $\mathrm{H}^{+}$from the organic acid and the release of soluble carbohydrates.

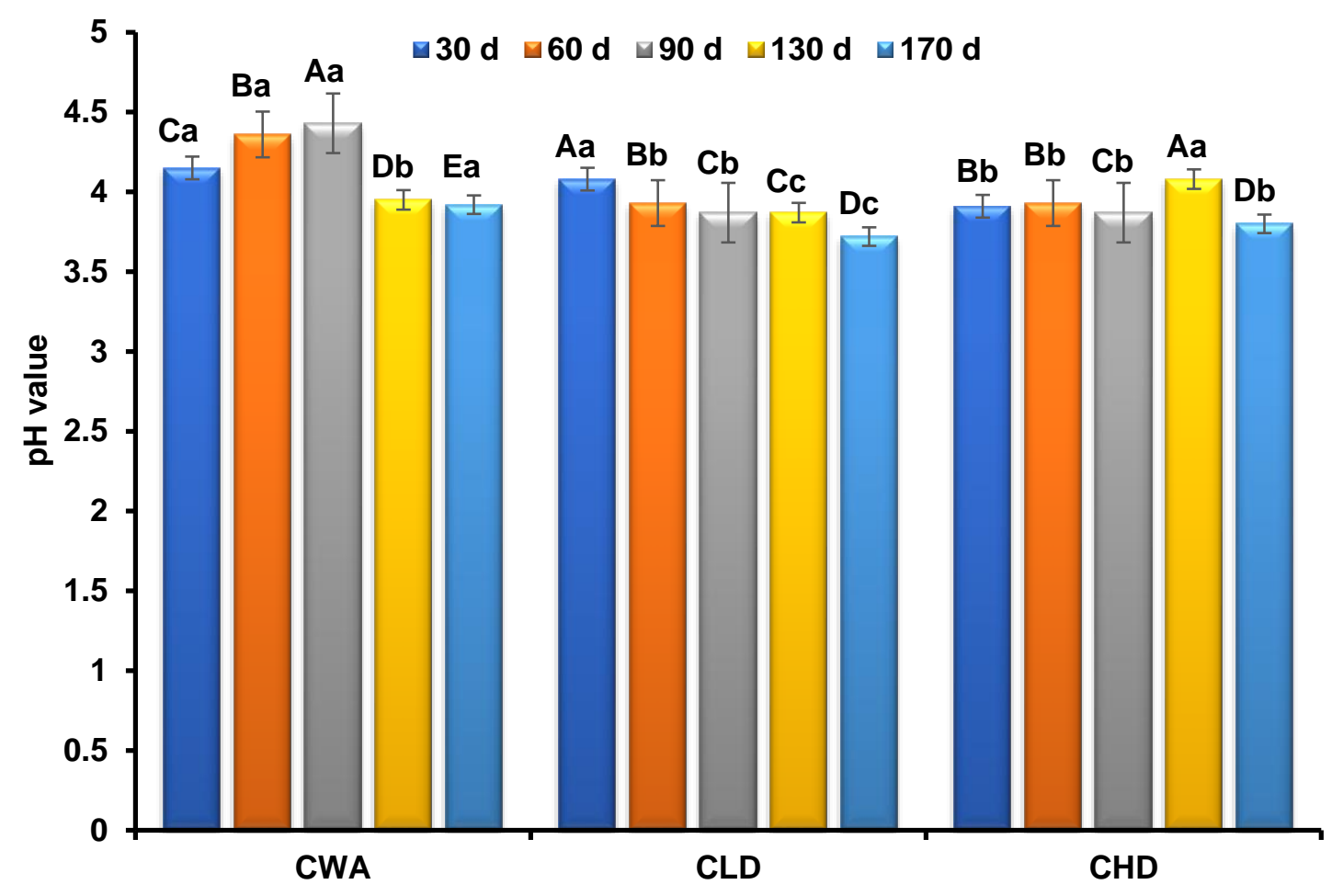

Fig. 2. Dynamic effects of cellulase dosage on fermentation $\mathrm{pH}$ values, where CWA contained no cellulase, CLD contained a low dosage of cellulase $(0.1 \%)$, and CHD contained a high dosage of cellulase $(0.3 \%)$. The different lowercase letters indicate significant differences at $p<0.05$ between the different groups at the same time, while the different capital letters indicate significant differences at $p<0.05$ for the same groups at different times.

Concentration changes in the organic acids during the ensiling process are listed in Table 3. The concentration of LA in all three treated groups initially increased, followed by some decreases, which was further followed by increases in their maximum values at 
60 days. It should be noted that the concentrations of LA in the CLD and CHD groups were higher than in CWA, while the maximum value was obtained in the CHD group, except at 130 days. The results showed that the addition of cellulase enhanced the production of LA, which was consistent with the relative abundance of LA bacteria in Table 3 . The concentration of acetic acid (AA) in CWA and CHD increased steadily, while in the CLD group, it showed a transient increase (30-90 days) followed by a decrease. On day 30, both CLD and CHD groups had higher AA content than CWA. However, between 60 and 130 days, the concentration of AA in the CHD group remained lower than in the CWA group.

Moreover, the concentrations of butyric acid (BA) in the CLD and CHD groups were higher than in the CWA group, while propionic acid (PPA) and BA content were less than $0.5 \%$ of the total concentration of organic acid during the entire process. These results were consistent with the requirements for high-quality ensiling (Agneessens et al. 2015). The ethanol (EA) content of CWA decreased continuously, while in the CLD and CHD groups, it increased. Based on the calculated contents of the organic acids, the ratios of lactic acid/acetic acid (LA/AA) and lactic acid/total organic acid (LA/TOA) decreased from 7.44 and 0.82 (30 days) to 4.06 and 0.75 (30 days), respectively, for all three groups during co-ensiling. These ratios were higher in CHD and CLD than in CWA.

Ammonia nitrogen (AN) content represents protein degradation, and a decline in AN content indicates lower CP consumption and better preservation of silage (Luo et al. 2021). Thus, as shown in Fig. 3, the AN value in the CWA group was stable from 30 to 90 days, followed by a significant decrease $(\mathrm{p}<0.05)$ after 130 days, and then stabilized afterward. The AN values of the CLD group were stable from 1.20 to 1.25 between 30 and 60 days, which significantly $(\mathrm{p}<0.05)$ increased on day 90 and stabilized afterward. In the CHD group, the AN values increased first to the maximum $(2.83 \pm 0.38)$ after 90 days, and then decreased. Furthermore, CLD and CHD had significantly ( $\mathrm{p}<0.05)$ lower AN values than the CWA group between 30 and 60 days, which increased and stabilized on day 90 , and finally significantly $(\mathrm{p}<0.05)$ increased on day 170 . These results indicated that the addition of cellulase reduced protein decomposition during the co-ensiling stage between the 30- and 60-day period. Although the AN values increased after 90 days, the values were still within the recommended range (less than 10\%) for high-quality ensiling (Ni et al. 2017). Generally, a successful ensiling process requires that the concentrations of LA, AA, and PPA be no more than $60 \%$, less than $4 \%$, and $1.5 \%$ of the total organic acid content, respectively. In addition, a ratio of LA/AA higher than two and a concentration of BA close to zero is required (Colombatto et al. 2004b). Filya (2003) reported that a high-quality ensiling process should have high LA $(>60 \%)$, low BA $(<2 \%)$, and low AN content $(<$ $9 \%)$, and a low $\mathrm{pH}$ value $(<4.2)$. Thus, it was concluded that the co-ensiling of DCS and $\mathrm{CW}$ achieved good long-term storage performance (170 days), and the addition of cellulase promoted silage quality. 


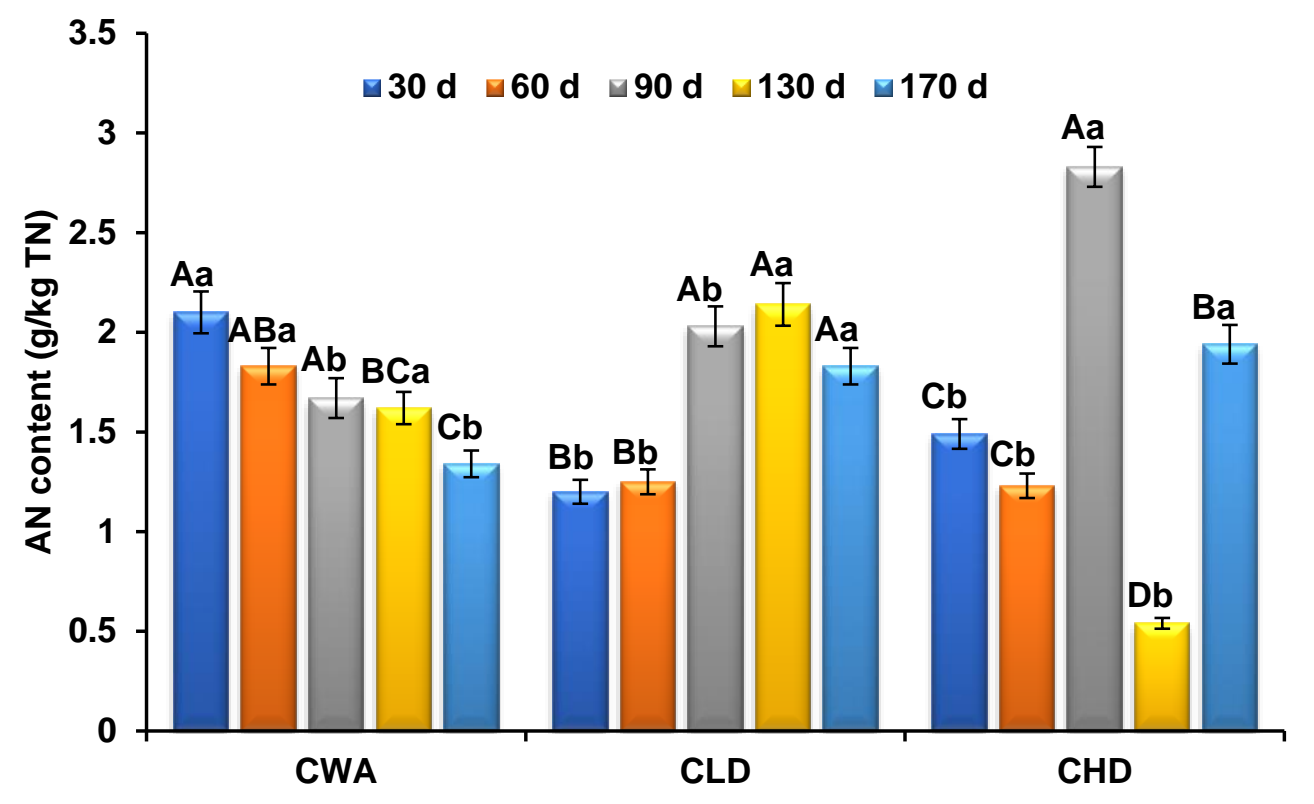

Fig. 3. Dynamic effects of cellulase dosage on the ammonia nitrogen (AN) content, where CWA had no cellulase addition, CLD contained a low dosage of cellulase $(0.1 \%)$, and CHD contained a high dosage of cellulase $(0.3 \%)$. The different lowercase letters indicate significant differences at $p<0.05$ between the different groups at the same time, while the different capital letters indicate significant differences at $p<0.05$ for the same groups at different times. 
Table 3. Dynamic Effects of Cellulase Dosage on the Formation Patterns of Low-molecular Fermentation Products (mg/g DM)

\begin{tabular}{|c|c|c|c|c|c|c|c|c|}
\hline & $\begin{array}{c}\text { Time } \\
\text { (d) }\end{array}$ & LA & AA & PPA & BA & EA & LA/AA & LA/TOA \\
\hline \multirow{5}{*}{ CWA } & 30 & $3.78 \pm 0.04 \mathrm{Bb}$ & $0.77 \pm 0.02 \mathrm{Cb}$ & $0.09 \pm 0.01 \mathrm{ABb}$ & $0.25 \pm 0.03 \mathrm{Bb}$ & $0.71 \pm 0.04 \mathrm{Aa}$ & 4.91 & 0.77 \\
\hline & 60 & $5.07 \pm 0.03 \mathrm{Ac}$ & $1.27 \pm 0.05 \mathrm{BCa}$ & $0.08 \pm 0.01 \mathrm{Bb}$ & $0.21 \pm 0.01 \mathrm{Cb}$ & $0.67 \pm 0.05 \mathrm{ABa}$ & 3.99 & 0.76 \\
\hline & 90 & $3.05 \pm 0.02 \mathrm{Cc}$ & $1.45 \pm 0.08 \mathrm{Bb}$ & $0.11 \pm 0.02 \mathrm{Aa}$ & $0.32 \pm 0.02 \mathrm{Aa}$ & $0.50 \pm 0.02 \mathrm{Cc}$ & 2.10 & 0.62 \\
\hline & 130 & $2.51 \pm 0.02 \mathrm{Db}$ & $1.11 \pm 0.06 \mathrm{BCa}$ & $0.10 \pm 0.00 \mathrm{ABa}$ & $0.15 \pm 0.02 \mathrm{Db}$ & $0.58 \pm 0.05 \mathrm{BCc}$ & 2.26 & 0.65 \\
\hline & 170 & $3.77 \pm 0.01 \mathrm{Bc}$ & $2.06 \pm 0.58 \mathrm{Aa}$ & ND & $0.01 \pm 0.00 \mathrm{~Eb}$ & $0.56 \pm 0.09 \mathrm{Cb}$ & 1.83 & 0.65 \\
\hline \multirow{5}{*}{ CLD } & 30 & $3.53 \pm 0.07 \mathrm{Dc}$ & $0.87 \pm 0.02 \mathrm{Da}$ & $0.09 \pm 0.01 \mathrm{Ab}$ & $0.23 \pm 0.03 \mathrm{Cb}$ & $0.33 \pm 0.01 \mathrm{Cc}$ & 4.06 & 0.75 \\
\hline & 60 & $5.76 \pm 0.01 \mathrm{Ab}$ & $1.36 \pm 0.10 \mathrm{Ba}$ & $0.10 \pm 0.01 \mathrm{Aab}$ & $0.43 \pm 0.11 \mathrm{Aa}$ & $0.73 \pm 0.06 \mathrm{Ba}$ & 4.24 & 0.75 \\
\hline & 90 & $4.21 \pm 0.01 \mathrm{Cb}$ & $1.76 \pm 0.07 \mathrm{Aa}$ & $0.11 \pm 0.02 \mathrm{Aa}$ & $0.13 \pm 0.01 \mathrm{Db}$ & $0.98 \pm 0.02 \mathrm{Aa}$ & 2.39 & 0.68 \\
\hline & 130 & $4.23 \pm 0.02 \mathrm{Ca}$ & $1.16 \pm 0.07 \mathrm{Ca}$ & $0.12 \pm 0.03 \mathrm{Aa}$ & $0.35 \pm 0.06 \mathrm{Ba}$ & $1.07 \pm 0.12 \mathrm{Aa}$ & 3.65 & 0.72 \\
\hline & 170 & $5.16 \pm 0.01 \mathrm{Bb}$ & ND & ND & ND & ND & - & - \\
\hline \multirow{5}{*}{$\mathrm{CHD}$} & 30 & $6.25 \pm 0.02 \mathrm{Ba}$ & $0.84 \pm 0.03 \mathrm{Ca}$ & $0.17 \pm 0.02 \mathrm{Aa}$ & $0.37 \pm 0.06 \mathrm{ABa}$ & $0.63 \pm 0.03 \mathrm{Cb}$ & 7.44 & 0.82 \\
\hline & 60 & $7.13 \pm 0.07 \mathrm{Aa}$ & $1.06 \pm 0.02 \mathrm{Bb}$ & $0.11 \pm 0.02 \mathrm{Ba}$ & $0.40 \pm 0.05 \mathrm{Aa}$ & $0.66 \pm 0.13 \mathrm{Ca}$ & 6.73 & 0.82 \\
\hline & 90 & $5.10 \pm 0.10 \mathrm{Da}$ & $1.15 \pm 0.05 \mathrm{Bc}$ & $0.09 \pm 0.01 \mathrm{Ba}$ & $0.11 \pm 0.01 \mathrm{Cb}$ & $0.82 \pm 0.01 \mathrm{Bb}$ & 4.43 & 0.79 \\
\hline & 130 & $1.26 \pm 0.01 \mathrm{Ec}$ & $0.81 \pm 0.08 \mathrm{Cb}$ & $0.10 \pm 0.02 \mathrm{Ba}$ & $0.31 \pm 0.04 \mathrm{Ba}$ & $0.85 \pm 0.07 \mathrm{Bb}$ & 1.56 & 0.51 \\
\hline & 170 & $5.96 \pm 0.02 \mathrm{Ca}$ & $2.49 \pm 0.06 \mathrm{Aa}$ & ND & $0.08 \pm 0.03 \mathrm{Ca}$ & $2.93 \pm 0.04 \mathrm{Aa}$ & 2.39 & 0.70 \\
\hline
\end{tabular}

CWA: no cellulase addition; CLD: low dosage of cellulase (0.1\%); and CHD: high dosage of cellulase (0.3\%). LA: lactic acid; AA: acetic acid; PPA: propionic acid; BA: butyrate acid; EA: ethanol alcohol; and LA/TOA: lactic acid/total organic acid; and ND: not detected.

The same column with different lowercase letters indicates significant differences at $p<0.05$ between different groups at the same time, and the same column with the same lowercase letters indicates no significant differences at $p>0.05$ between different groups at the same time. The same column with different capital letters indicates significant differences at $p>0.05$ for the same groups at different times, and the same column with the same capital letters indicates no significant differences at $p<0.05$ for the same groups at different times. 


\section{Influence of Cellulase on Bacterial Community during Co-ensiling}

Alpha diversity analysis

For the bacterial analysis, Chao and ACE indices were used to estimate the number of OTUs in the communities. The Simpson and Shannon indices were used to estimate one of the microbial diversity indices in the sample. As shown in Table 4, the Chao and ACE index values of the CWA group ranged from 223.00 to 716.51 , and 246.64 to 730.51 , respectively. However, the Chao and ACE index values of the CLD group ranged from 328.28 to 856.00 , and 366.49 to 739.48 , respectively. Compared to the CWA and CLD groups, a reduction in Chao and ACE index values was observed for the CHD group, except for the samples after 30 days. This indicated that the addition of cellulase enhanced the abundance of microbial communities (Du et al. 2020). The Simpson index ranged from 0.56 to 0.97 during the ensiling period, while for the Shannon index, a decrease was observed for the CHD group, indicating that the addition of cellulase improved LA fermentation, and thus reduced the diversity of the bacterial communities (Du et al. 2020; Wang et al. 2020).

Table 4. Alpha Index Diversities of the Samples

\begin{tabular}{|c|c|c|c|c|c|}
\hline $\begin{array}{c}\text { Time } \\
(\mathrm{d})\end{array}$ & Group & Chao index & ACE index & $\begin{array}{c}\text { Simpson } \\
\text { index }\end{array}$ & $\begin{array}{c}\text { Shannon } \\
\text { index }\end{array}$ \\
\hline \multirow{3}{*}{30} & CWA & 434.27 & 453.28 & 0.82 & 3.53 \\
\cline { 2 - 6 } & CLD & 701.08 & 739.48 & 0.85 & 4.14 \\
\cline { 2 - 6 } & CHD & 576.13 & 596.83 & 0.82 & 3.70 \\
\hline \multirow{3}{*}{60} & CWA & 506.77 & 505.16 & 0.82 & 3.63 \\
\cline { 2 - 6 } & CLD & 328.28 & 366.49 & 0.84 & 3.74 \\
\cline { 2 - 6 } & CHD & 445.73 & 458.19 & 0.83 & 3.49 \\
\hline \multirow{3}{*}{90} & CWA & 223.00 & 246.64 & 0.92 & 4.58 \\
\cline { 2 - 6 } & CLD & 856.00 & 387.49 & 0.97 & 7.27 \\
\hline \multirow{3}{*}{130} & CHD & 214.00 & 253.63 & 0.86 & 3.37 \\
\cline { 2 - 6 } & CWA & 564.80 & 613.14 & 0.88 & 4.57 \\
\cline { 2 - 6 } & CLD & 566.00 & 580.38 & 0.87 & 4.32 \\
\hline \multirow{3}{*}{170} & CHD & 513.06 & 510.56 & 0.69 & 2.93 \\
\cline { 2 - 6 } & CWA & 716.51 & 730.51 & 0.70 & 3.27 \\
\cline { 2 - 6 } & CHD & 713.27 & 734.71 & 0.91 & 4.92 \\
\hline
\end{tabular}

CWA had no cellulase addition, CLD contained a low dosage of cellulase $(0.1 \%)$, and CHD contained a high dosage of cellulase $(0.3 \%)$.

Effect of cellulase on microbial communities during the co-ensiling process

The microbial communities at the phylum level of the co-ensiling process with and without cellulase are presented in Fig. 4. For the DCS, the dominant bacteria at the phylum level included Firmicutes and Proteobacteria, while for $\mathrm{CW}$, Bacteroidetes and Proteobacteria were the primary bacteria. For both ensiling systems, phylum Firmicutes and Proteobacteria were the dominant bacteria, with a relative abundance of 87.9 to $99.4 \%$ 
per total reads of bacteria. Meanwhile, the relative abundance of phylum Bacteroidetes ranged from $0.5 \%$ to $10.2 \%$ during the co-ensiling process. In addition, the relative abundance of phyla Actinobacteria, Cyanobacteria, and Verrucomicrobia was all less than $1.0 \%$. Thus, compared to CWA, an increase of 5 to $174 \%$ in the relative abundance of Firmicutes was observed for the systems with cellulase addition (CLD and CHD), while a decrease of 8 to $68 \%$ in the relative abundance of Proteobacteria occurred. Phylum Firmicutes can degrade a variety of macromolecular compounds, such as cellulose, starch, and protein (Kung and Ranjit 2001). Therefore, an increase in the relative abundance contributed to the increase in the WSC concentration of the system with cellulase addition, coupled with a decrease in the amount of acid detergent and neutral detergent fibers. In contrast, phylum Proteobacteria, including Escherichia coli and Salmonella, negatively impacted ensiling, due to the competition for nutrients between the lactic acid bacteria and the production of biological amines (Kadivar and Stapleton 2003).

The microbial communities at the genus level for the raw material and co-ensiling process with and without cellulase are presented in Fig. 5. For the DCS, the dominant bacteria at the genus level included Carnobacterium and Enterobacter, while for the CW, genus Pseudomonas and Flavobacterium were the primary bacteria. For the co-ensiling system without cellulase (CWA), there were different microbial communities with a change in ensiling time. The dominant bacteria included Paralactobacillus (15.4 to $22.9 \%$ ), Lactobacillus (20.7 to 35.4\%), and Enterobacter (36.0 to 44.9\%) between 30 and 60 days. Furthermore, the dominant bacteria shifted from genus Enterobacter, Erwinia, Pseudomonas, Staphylococcus, and the family, Moraxellaceae, to genus Paralactobacillus, Lactobacillus, Klebsiella, and Rahnella when the ensiling time increased from 90 to 130 days. At an ensiling time of 170 days, the relative abundance of Lactobacillus reached 62.1\%. For the co-ensiling system with cellulase, genera Paralactobacillus, Lactobacillus, and Enterobacter were the primary bacteria. The dominant bacteria of the CLD and CHD groups were similar to those of the CWA group between 30 and 60 days, with a higher abundance of total LA bacteria and lower abundance of Enterobacter observed, compared to CWA. Notably, after 90 days, Leuconostoc and Enterococcus were newly identified in the CLD and CHD groups, and Photobacterium was identified in the CLD group. After 130 days, Rahnella was identified in the CLD and CHD groups, with relative abundance values of $15 \%$ and $11.8 \%$, respectively. Enterobacter and Lactococcus disappeared from groups CLD and CHD between 130 and 170 days, while the relative abundance of Leuconostoc increased to $13.6 \%$ in the CLD group. The genus Lactobacillus is the preferred bacteria in silage, as it can metabolize WSCs to LA, and contributes to the decrease in $\mathrm{pH}$ and inhibits undesirable bacteria (Mu et al. 2020). In addition, Paralactobacillus is a homofermentative LA bacterium, producing L-(+)- as well as D-(-)lactic acid from glucose, and a proposal for reclassification as genus Lactobacillus has been put forward (Zheng et al. 2020; Leisner et al. 2000; Haakensen et al. 2011). Enterobacter, Pseudomonas, and Rahnella are considered undesirable bacteria in silage, as they compete for available WSC with LAB, produce endotoxins, and reduce protein content (Zhao et al. 2021; Zi et al. 2021). Based on the proposed reclassification, a higher relative abundance of Lactobacillus was achieved for the system with cellulase addition. During the coensiling of DCS and CW, the addition of cellulase increased the abundance of LA bacteria, which eliminated Enterobacter after 130 days, and significantly $(P<0.05)$ improved the abundance of Lactobacillus. In the CHD group, the abundance of Lactobacillus reached $69.1 \%$ and $82.5 \%$ after 130 and 170 days, respectively, and the abundance of Lactobacillus was persistently higher in the CHD group than in the CLD and CWA groups. In addition, 
a decrease of 11 to $22 \%$ and 20 to $57 \%$ in the relative abundance of Enterococcus and Rahnella was observed. The results indicated that the enhanced production of WSC caused by the addition of cellulase stimulated the growth of Lactobacillus. Similar results have been reported in previous studies. For example, Xu et al. (2020) reported that cellulase with Lactobacillus plantarum A1 performed well in fiber degradation during the coensiling of corn stalk and potato pulp. In addition, an improvement in the silage quality of mulberry leaves was observed with the application of cellulase and Lactobacillus casei LC (He et al. 2019).

Homo- and heterolactic fermentation are the common pathways for producing LA. Among them, LA is the primary production for homolactic fermentation, whereas heterolactic fermentation produces carbon dioxide, LA, ethanol, or AA (Muck et al. 2018). Kung and Ranjit (2001) reported that homolactic fermentation dominated with an LA/AA ratio higher than 3 . Therefore, there was a shift from homolactic fermentation to heterolactic fermentation when the ensiling time increased from 30 to 60 days, and from 130 to 170 days, coupled with the dominant LAB changes from Paralactobacillus and Lactobacillus to Lactobacillus for both co-ensiling systems (Fig. 6). Furthermore, the addition of cellulase prolonged the homolactic fermentation time and improved the relative abundance of Lactobacillus.

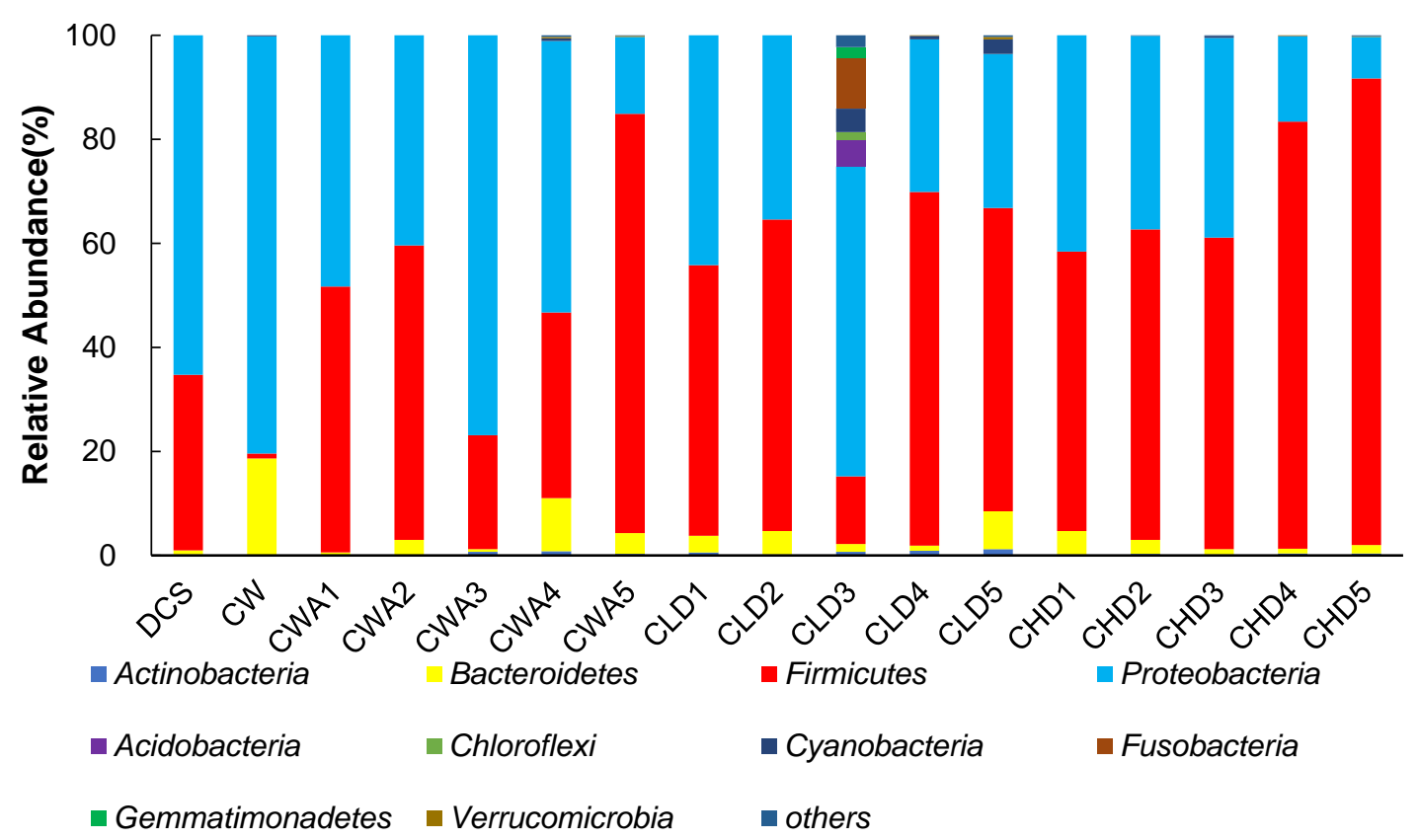

Fig. 4. Relative abundance of bacteria $16 \mathrm{~S}$ rRNA genes at the phylum level, where DCS: dry corn stover; CW: cabbage waste; CLD: cellulase addition dosage of $0.1 \%$; $\mathrm{CHD}$ : cellulase addition dosage of $0.3 \%) ; 1: 30 \mathrm{~d} ; 2: 60 \mathrm{~d} ; 3: 90 \mathrm{~d} ; 4: 130 \mathrm{~d} ; 5: 170 \mathrm{~d}$ 


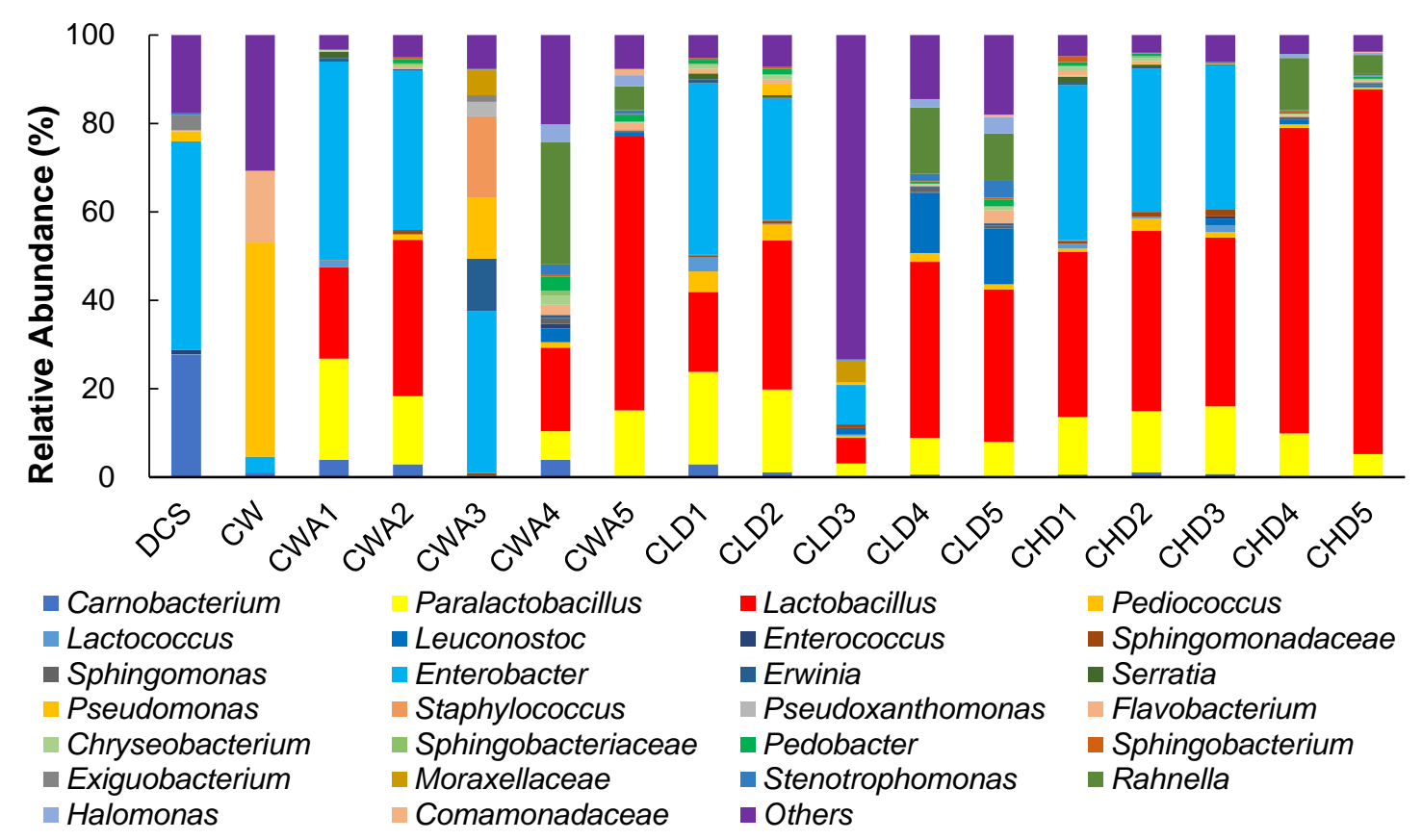

Fig. 5. Relative abundance of bacteria 16S rRNA genes at the genus level; DCS: dry corn stover; CW: cabbage waste; CLD: cellulase addition dosage of $0.1 \%$; CHD: cellulase addition dosage of $0.3 \% ; 1: 30 \mathrm{~d} ; 2: 60 \mathrm{~d} ; 3: 90 \mathrm{~d} ; 4: 130 \mathrm{~d} ; 5: 170 \mathrm{~d}$

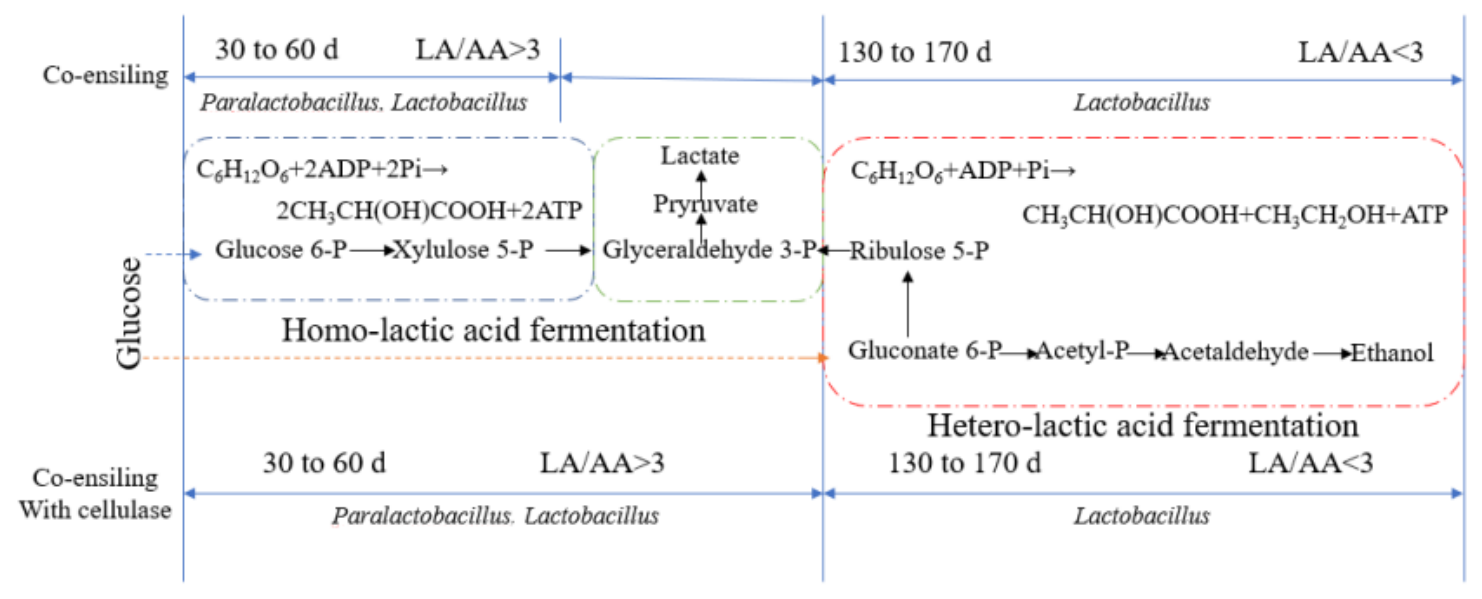

Fig. 6. The pathway of the co-ensiling system without and with cellulase

\section{CONCLUSIONS}

1. The experimental results showed that the co-ensiling performance of air-dried corn stover (DCS) and cabbage waste (CW) was improved by the addition of cellulase. Both high $(0.3 \%)$ and low $(0.1 \%)$ dosages of cellulase effectively preserved the water-soluble carbohydrates, promoted the production of lactic acid (LA), and significantly decreased the fermentation $\mathrm{pH}$ values and the neutral detergent and acid detergent fibers. 
2. Furthermore, the addition of cellulase increased the relative abundance of desirable Lactobacillus and decreased the number of undesirable microorganisms such as Enterobacter, Pseudomonas, and Rahnella. This ultimately improved the quality of the DCS and CW silage.

3. Considering both the ensiling performance and enzyme cost, this study recommends a cellulase addition of $0.1 \%$ to fresh matter for the co-ensiling of DCS and $\mathrm{CW}$, to enhance silage fermentation quality.

\section{ACKNOWLEDGEMENTS}

This work was financially supported by the National Natural Science Foundation of China (Grant Nos. 51666010 and 51366009), the China Postdoctoral Science Foundation Funded Project (Grant Nos. 2018M631217 and 2019T120961), West Light Foundation of the Chinese Academy of Sciences (Grant No. 2018XBZG XBQNXZ A), the Red Willow First-class Discipline Project (No. 0807J1), the Red Willow Distinguished Young Talents (Grant No. JQ2020), and First-class Discipline Project of the Lanzhou University of Technology (Grant No. 0807J1). We thank LetPub (www.letpub.com) for its linguistic assistance during the preparation of this manuscript.

\section{REFERENCES CITED}

Adesogan, A. T., and Newman, Y. C. (2014). Silage Harvesting, Storing, and Feeding, Florida Forage Handbook, Gainesville, FL, USA.

Agneessens, L., Viaene, J., Nest, T. V., Vandecasteele, B., and De Neve, S. (2015). "Effect of ensilaged vegetable crop residue amendments on soil carbon and nitrogen dynamics," Scientia Horticulturae 192, 311-319. DOI: 10.1016/j.scienta.2015.06.034

Chen, Y., Zhao, Z., Zou, H., Yang, H., and Gu, L. (2019). "Digestive performance of sludge with different crop straws in mesophilic anaerobic digestion," Bioresource Technology 289, article ID 121595. DOI: 10.1016/j.biortech.2019.121595

Colombatto, D., Mould, F. L., Bhat, M. K., Phipps, R. H., and Owen, E. (2004a). “In vitro evaluation of fibrolytic enzymes as additives for maize (Zea mays L.) silage," Animal Feed Science and Technology 111(1-4), 111-128. DOI:

10.1016/j.anifeedsci.2003.08.010

Colombatto, D., Mould, F. L., Bhat, M. K., Phipps, R. H., and Owen, E. (2004b). "In vitro evaluation of fibrolytic enzymes as additives for maize (Zea mays L.) silage: II. Effects on rate of acidification, fibre degradation during ensiling and rumen fermentation." Animal Feed Science and Technology 111(1-4), 129-143. DOI: 10.1016/j.anifeedsci.2003.08.011

Desta, S. T., Yuan, X., Li, J., and Shao, T. (2016). "Ensiling characteristics, structural and nonstructural carbohydrate composition and enzymatic digestibility of Napier grass ensiled with additives," Bioresource Technology 221, 447-454. DOI: 10.1016/j.biortech.2016.09.068

Du, Z., Sun, L., Chen, C., Lin, J., Yang, F., and Cai, Y. (2020). "Exploring microbial community structure and metabolic gene clusters during silage fermentation of paper 
mulberry, a high-protein woody plant," Animal Feed Science and Technology 275, 114766. DOI: $10.1016 /$ j.anifeedsci.2020.114766

Filya, I. (2003). "The effect of Lactobacillus buchneri and Lactobacillus plantarum on the fermentation, aerobic stability, and ruminal degradability of low dry matter corn and sorghum silages," Journal of Dairy Science 86(11), 3575-3581. DOI: 10.3168/jds.S0022-0302(03)73963-0

Gallegos, D., Wedwitschka, H., Moeller, L., Weinrich, S., and Stinner, W. (2018). "Mixed silage of Elodea and wheat straw as a substrate for energy production in anaerobic digestion plants," Energy, Sustainability and Society 8(1), 7. DOI: 10.1186/s13705-018-0148-1

Haakensen, M., Pittet, V., and Ziola, B. (2011). "Reclassification of Paralactobacillus selangorensis (Leisner et al. 2000) as Lactobacillus selangorensis comb. nov.," International Journal of Systematic and Evolutionary Microbiology 61(12), 29792983. DOI: 10.1099/ijs.0.027755-0

He, Y., Liu, F., Gong, L., Zhu, Z., Ding, Y., Wang, C., Xue, Y., Rui, H., Tao, Z., Zhang, D., et al. (2015). "Significantly improving enzymatic saccharification of high crystallinity index's corn stover by combining ionic liquid [Bmim] $\mathrm{Cl}-\mathrm{HCl}-$ water media with dilute $\mathrm{NaOH}$ pretreatment," Bioresource Technology 189, 421-425. DOI: 10.1016/j.biortech.2015.04.047

Hess, J. R., Kenney, K. L., Wright, C. T., Perlack, R., and Turhollow, A. (2009). "Corn stover availability for biomass conversion: Situation analysis," Cellulose 16(4), 599619. DOI: 10.1007/s10570-009-9323-z

Hillion, M., Moscoviz, R., Trably, E., Leblanc, Y., Bernet, N., Torrijos, M., and Escudié, R. (2018). "Co-ensiling as a new technique for long-term storage of agro-industrial waste with low sugar content prior to anaerobic digestion," Waste Management 71, 147-155. DOI: 10.1016/j.wasman.2017.10.024

Janke, L., McCabe, B. K., Harris, P., Hill, A., Lee, S., Weinrich, S., Marchuk, S., and Baillie, C. (2019). "Ensiling fermentation reveals pre-treatment effects for anaerobic digestion of sugarcane biomass: An assessment of ensiling additives on methane potential," Bioresource Technology 279, 398-403. DOI: 10.1016/j.biortech.2019.01.143

Kadivar, H., and Stapleton, A. E. (2003). "Ultraviolet radiation alters maize phyllosphere bacterial diversity," Microbial Ecology 45(4), 353-361. DOI: 10.1007/s00248-0021065-5

Kholif, A. E., Elghandour, M. M. Y., Rodríguez, G. B., Olafadehan, O. A., and Salem, A. Z. M. (2017). "Anaerobic ensiling of raw agricultural waste with a fibrolytic enzyme cocktail as a cleaner and sustainable biological product," Journal of Cleaner Production 142(4), 2649-2655. DOI: 10.1016/j.jclepro.2016.11.012

Kung, L., and Ranjit, N. K. (2001). "The effect of Lactobacillus buchneri and other additives on the fermentation and aerobic stability of barley silage," Journal of Dairy Science 84(5), 1149-1155. DOI: 10.3168/jds.S0022-0302(01)74575-4

Leisner, J. J., Vancanneyt, M., Goris, J., Christensen, H., and Rusul, G. (2000). "Description of Paralactobacillus selangorensis gen. nov., sp. nov., a new lactic acid bacterium isolated from chili bo, a Malaysian food ingredient," International Journal of Systematic and Evolutionary Microbiology 50(1), 19-24. DOI: 10.1099/0020771350-1-19

Leyva, A., Quintana, A., Sánchez, M., Rodríguez, E. N., Cremata, J., and Sánchez, J. C. (2008). "Rapid and sensitive anthrone-sulfuric acid assay in microplate format to 
quantify carbohydrate in biopharmaceutical products: Method development and validation," Biologicals 36(2), 134-141. DOI: 10.1016/j.biologicals.2007.09.001

Li, F., Ding, Z., Ke, W., Xu, D., Zhang, P., Bai, J., Mudassar, S., Muhammad, I., and Guo, X. (2019). "Ferulic acid esterase-producing lactic acid bacteria and cellulase pretreatments of corn stalk silage at two different temperatures: Ensiling characteristics, carbohydrates composition and enzymatic saccharification," Bioresource Technology 282, 211-221. DOI: 10.1016/j.biortech.2019.03.022

Li, F., Ke, W., Ding, Z., Bai, J., Zhang, Y., Xu, D., Li, Z., and Guo, X. (2020). "Pretreatment of Pennisetum sinese silages with ferulic acid esterase-producing lactic acid bacteria and cellulase at two dry matter contents: Fermentation characteristics, carbohydrates composition and enzymatic saccharification," Bioresource Technology 295, 122261. DOI: 10.1016/j.biortech.2019.122261

Li, J., Yuan, X., Dong, Z., Mugabe, W., and Shao, T. (2018). “The effects of fibrolytic enzymes, cellulolytic fungi and bacteria on the fermentation characteristics, structural carbohydrates degradation, and enzymatic conversion yields of Pennisetum sinese silage," Bioresource Technology 264, 123-130. DOI: 10.1016/j.biortech.2018.05.059

Li, L., Zhen, F., Sun, Y., Yuan, Z., Kong, X., Zhou, X., and Ni, H. (2014). "Low-cost additive improved silage quality and anaerobic digestion performance of napiergrass," Bioresource Technology 173, 439-442. DOI:

10.1016/j.biortech.2014.09.011

Li, M., Zi, X., Zhou, H., Lv, R., Tang, J., and Cai, Y. (2019). "Silage fermentation and ruminal degradation of cassava foliage prepared with microbial additive," $A M B$ Express 9. DOI:10.1186/s13568-019-0906-2

He, L., Zhou, W., Wang, C., Yang, F., and Chen, X. (2019). "Effect of cellulase and Lactobacillus casei on ensiling characteristics, chemical composition, antioxidant activity, and digestibility of mulberry leaf silage," Journal of Dairy Science 102(11), 9919-9931. DOI: 10.3168/jds.2019-16468

Hu, Z., Ma, D., Niu, H., Chang, J., Yu, J., Tong, Q., and Li, S. (2021). "Enzyme additives influence bacterial communities of Medicago sativa silage as determined by Illumina sequencing,"AMB Express 11. DOI:10.1186/s13568-020-01158-5

Luo, R., Zhang, Y., Wang, F., Liu, K., Huang, G., Zheng, N., and Wang, J. (2021). "Effects of sugar cane molasses addition on the fermentation quality, microbial community, and tastes of alfalfa silage," Animals 11, 355. DOI:10.3390/ani11020355

Lynch, J. P., Baah, J., and Beauchemin, K. A. (2015). "Conservation, fiber digestibility, and nutritive value of corn harvested at 2 cutting heights and ensiled with fibrolytic enzymes, either alone or with a ferulic acid esterase-producing inoculant," Journal of Dairy Science 98(2), 1214-1224. DOI: 10.3168/jds.2014-8768

Mu, L., Xie, Z., Hu, L., Chen, G., and Zhang, Z. (2020). "Cellulase interacts with Lactobacillus plantarum to affect chemical composition, bacterial communities, and aerobic stability in mixed silage of high-moisture amaranth and rice straw," Bioresource Technology 315,123772. DOI: 10.1016/J.BIORTECH.2020.123772

Muck, R. E., Nadeau, E. M. G., Mcallister, T. A., Contreras-Govea, F. E., Santos, M. C., and Kung, L. J. (2018). "Silage review: Recent advances and future uses of silage additives," Journal of Dairy Science 101(5), 3980-4000. DOI: 10.3168/jds.201713839

Ni, K., Wang, F., Zhu, B., Yang, J., Zhou, G., Pan, Y., Tao, Y., and Zhong, J. (2017). "Effects of lactic acid bacteria and molasses additives on the microbial community 
and fermentation quality of soybean silage," Bioresource Technology 238, 706-715. DOI: 10.1016/j.biortech.2017.04.055

Sun, Q., Gao, F., Yu, Z., Tao, Y., Zhao, S., and Cai, Y. (2011). "Fermentation quality and chemical composition of shrub silage treated with lactic acid bacteria inoculants and cellulase additives," Animal Science Journal 83(4), 305-309. DOI: 10.1111/j.17400929.2011.00962.x

Ren, H., Sun, W., Yan, Z., Zhang, Y., Wang, Z., Song, B., Zheng, Y., and Li, J. (2021). "Bioaugmentation of sweet sorghum ensiling with rumen fluid: Fermentation characteristics, chemical composition, microbial community, and enzymatic digestibility of silages," Journal of Cleaner Production 294, 126308. DOI:

10.1016/j.jclepro.2021.126308

Ren, H., Wang, C., Fan, W., Zhang, B., Li, Z., and Li, D. (2018). "Effects of formic or acetic acid on the storage quality of mixed air-dried corn stover and cabbage waste, and microbial community analysis," Food Technology and Biotechnology 56(1), 7182. DOI: $10.17113 / \mathrm{ftb} .56 .01 .18 .5455$

Robinson, P. H., Swanepoel, N., Heguy, J. M., Price, P., and Meyer, D. M. (2016). "Total 'shrink' losses, and where they occur, in commercially sized silage piles constructed from immature and mature cereal crops," Science of The Total Environment 559, 4552. DOI: 10.1016/j.scitotenv.2016.03.103

Romero, J. J., Zarate, M. A., Arriola, K. G., Gonzalez, C. F., Silva-Sanchez, C., Staples, C. R., and Adesogan, A. T. (2015). "Screening exogenous fibrolytic enzyme preparations for improved in vitro digestibility of bermudagrass haylage," Journal of Dairy Science 98(4), 2555-2567. DOI: 10.3168/jds.2014-8059

Sargsyan, H., Trchounian, K., Gabrielyan, L., and Trchounian, A. (2016). "Novel approach of ethanol waste utilization: Biohydrogen production by mixed cultures of dark- and photo-fermentative bacteria using distillers grains," International Journal of Hydrogen Energy 41(4), 2377-2382. DOI: 10.1016/j.ijhydene.2015.11.082

Vandecasteele, B., Willekens, K., Steel, H., D’Hose, T., Waes, C. V., and Bert, W. (2017). "Feedstock mixture composition as key factor for C/P ratio and phosphorus availability in composts: Role of biodegradation potential, biochar amendment and calcium content," Waste \& Biomass Valorization 8(8), 2553-2567. DOI: 10.1007/s12649-016-9762-3

Vervaeren, H., Hostyn, K., Ghekiere, G., and Willems, B. (2010). "Biological ensilage additives as pretreatment for maize to increase the biogas production," Renewable Energy 35(9), 2089-2093. DOI: 10.1016/j.renene.2010.02.010

Wang, S., Zhao, J., Dong, Z., Li, J., Kaka, N. A., and Shao, T. (2020). "Sequencing and microbiota transplantation to determine the role of microbiota on the fermentation type of oat silage," Bioresource Technology 309, 123371. DOI: 10.1016/j.biortech.2020.123371

Weinberg, Z. G., and Chen, Y. (2013). "Effects of storage period on the composition of whole crop wheat and corn silages," Animal Feed Science and Technology 185(3-4), 196-200. DOI: 10.1016/j.anifeedsci.2013.08.009

Wu, P., Li, L., Jiang, J., Sun, Y., Yuan, Z., Feng, X., and Guo, Y. (2020). "Effects of fermentative and non-fermentative additives on silage quality and anaerobic digestion performance of Pennisetum purpureum," Bioresource Technology 297,122425. DOI: 10.1016/j.biortech.2019.122425

Xu, D., Ding, Z., Bai, J., Ke, W., Zhang, Y., Li, F., and Guo, X. (2020). "Evaluation of the effect of feruloyl esterase-producing Lactobacillus plantarum and cellulase 
pretreatments on lignocellulosic degradation and cellulose conversion of co-ensiled corn stalk and potato pulp," Bioresource Technology 310, 123476. DOI: 10.1016/j.biortech.2020.123476.

Zhao, Y., Yu, J., Liu, J., Yang, H., Gao, L., Yuan, X., Cui, Z., and Wang, X. (2016). "Material and microbial changes during corn stalk silage and their effects on methane fermentation," Bioresource Technology 222, 89-99. DOI: 10.1016/j.biortech.2016.09.113

Zhao, C., Wang, L., Ma, G., Jiang, X., Yang, J., Lv, J., and Zhang, Y. (2021). “Cellulase interacts with lactic acid bacteria to affect fermentation quality, microbial community, and ruminal degradability in mixed silage of soybean residue and corn stover," Animals 11(2), 334. DOI: 10.3390/ani11020334

Zheng, J., Wittouck, S., Salvetti, E., Franz, C. M. A. P., Harris, H. M. B., Mattarelli, P., O'Toole, P. W., Pot, B. D. F.,Vandamme, P., Walter, J., et al. (2020). “A taxonomic note on the genus Lactobacillus: Description of 23 novel genera, emended description of the genus Lactobacillus Beijerinck 1901, and union of Lactobacillaceae and Leuconostocaceae," International Journal of Systematic and Evolutionary Microbiology 70(4), 2782-2858. DOI: 10.1099/ijsem.0.004107

Zi, X., Li, M., Chen, Y., Lv, R., Zhou, H., and Tang, J. (2021). "Effects of citric acid and Lactobacillus plantarum on silage quality and bacterial diversity of king grass silage," Frontiers in Microbiology 12, 631096. DOI: 10.3389/fmicb.2021.631096

Article submitted: April 14, 2021; Peer review completed: June 27, 2021; Revised version accepted: July 26, 2021; Published: July 29, 2021.

DOI: 10.15376/biores.16.3.6342-6362 